6. Prokaza, V. (2014). 'History of Petrykivka painting'. Available at: http:// petrikivochka.blogspot.ru/p/blog-page.html/. [Accessed 10.11. 2017].

7. Spirina, M. (2016.). 'Ethno-Cultural Component in Modern Design'. Global Media Journal, January, no.1, [online] Available at: https://www.questia.com/read/ 1P3-4308187101/ethno-cultural-component-in-modern-design/. Accessed 10.03. 2018].Accessed 10.03. 2018].

8. Synergy. (2017). Akademik [Academician], [online] Available at: <https:// dic.academic.ru/dic.nsf/ruwiki/391174/75422/>. [Accessed 07.11.2017].

9. The uniqueness of Petrykivka in the works of Olena Yarmoliuk (2016). Slovo Prosvity [The Enlightenment Word], [online] Available at: http://slovoprosvity. org/2016/02/26/nepovtornist-petrikivki-v-robotax-oleni-yarmolyuk. [Accessed 10.11. 2017].

10. The main techniques of decorating in Petrykivka painting. (2011). Diplomba, [online] Available at: <http://diplomba.ru/work/91926> [Accessed 07.11. 2017].

(C) Гардабхадзе I. А., 2018

(C) Друзенко А. В., 2018

УДК 7.03:646:17.022.1

Михайлова Рада Дмитрівна, доктор мистеитвознавства, Київський національний університет технологій і дизайну, Київ, Украӥна, radami1818@gmail.com

Костюченко Олена Вікторівна, доктор психологічних наук, Київький національний університет культури і мистецтв, Київ, Україна g2069544@gmail.com

\title{
СТИЛЬ ОДЯГУ ТА ЙОГО РОЛЬ У ФОРМУВАННІ ІМІДЖУ
}

Мета роботи. Визначити i проаналізувати базові стилі одягу, їx характерні риси та властивості, значення одягового стилю для іміджу, що $\epsilon$ впродовж останніх десятиліть актуальною проблемою, залишаючись недостатньо висвітленими в українському мистецтвознавстві. Метою статті $\epsilon$ обгрунтування ролі одягового стилю у формуванні іміджу сучасної людини. Методами дослідження $\epsilon$ аналіз та синтез, історичний та компаративний підхід, типологічні побудування за мистецтвознавчими критеріями образності. На основі комплексного аналізу положень теорії та історії дизайну конкретизується поняття стилю щодо основних тенденцій моди; за методикою паралельного порівняння виявлено достовірну картину розвитку сучасних 
стилів одягу як основи іміджу. Наукова новизна роботи полягає в аналізі наукових даних із зазначеної проблематики, їх систематизація, відповідно до сучасних наукових мистецтвознавчих підходів, та підсумкове узагальнення; в зверненні до проблематики формування/проектування іміджу на теоретичному та практичному рівні, що в умовах значного інтересу різних фахівців індустрії моди, поки що не потребує більш докладного наукового мистецтвознавчого осмислення. Розкриття даного питання сприяє більшій ефективності проектування іміджу як на теоретичному, так і практичному рівнях. У висновках, підсумовано, що імідж людини формується завдяки різним складовим, де суттєве місце належить вибору стилю одягу. Знання актуальних стилістичних тенденцій моди, зокрема високої, та іï модифікацій, має важливе значення для вирішення актуальних питань позиціонування, презентації та самореалізації людини в суспільстві.

Ключові слова: мода, стиль, образ, імідж, типологія стилів одягу, стилістичні преференції, дизайн одягу, художня культура, мистецтво.

Михайлова Рада Дмитриевна, доктор искусствоведения, Киевский национальный университет технологий и дизайна, Киев, Украина

Костюченко Елена Викторовна, доктор психологических наук, доцент, Киевский национальный университет культуры и искусств, Киев, Украина

\section{Стиль одежды и его роль в формировании имиджа}

Цель работы. Определить и проанализировать базовые стили одежды, их характерные черты и свойства, значение стиля одежды для имиджа, который является на протяжении последних десятилетий актуальной проблемой, оставаясь недостаточно освещенными в украинском искусствоведении. Целью статьи является обоснование роли стиля одежды в формировании имиджа современного человека. Методами исследования являются анализ и синтез, исторический и компаративный подход, типологические построения по искусствоведческим критериям образности. На основе комплексного анализа положений теории и истории дизайна конкретизируется понятие стиля относительно основных тенденций моды; по методике параллельного сравнения выявлена достоверная картина развития современных стилей одежды как основы имиджа. Научная новизна работы заключается в анализе научных данных по данной проблематике, их систематизация в соответствии с современными научными искусствоведческими подходами и итоговое обобщение; в обращении к проблематике формирования / проектирования имиджа на теоретическом и практическом уровне, в условиях значительного интереса различных специалистов индустрии моды, пока не нуждается в более подробном научном искусствоведческом осмыслении. Раскрытие данного вопроса способствует большой эффективности проектирования имиджа как на теоретическом, так и практическом уровнях. Выводы. Подытожено, имидж человека формируется благодаря различным составляющим, где существенное место принадлежит выбору стиля одежды. Знание актуальных стилистических тенденций моды, в частности высокой, и ее модификаций, имеет важное 
значение для решения актуальных вопросов позиционирования, презентации и самореализации человека в обществе.

Ключевые слова: мода, стиль, образ, имидж, типология стилей одежды, стилистические преференции, дизайн одежды, художественная культура, искусство.

Mykhailova Rada, Doctor of Art Criticism, Kyiv National University of Technologies and Design, Kyiv, Ukraine

Kostiuchenko Olena, Doctor of Psychology, Kyiv National University of Culture and Arts, Kyiv, Ukraine

\section{Style of clothing and its role in image-making}

The purpose of the article is to define and analyze the basic styles of clothing, their characteristic features and properties, the importance of clothing style in imagemaking, which has been a topical issue over the last decades but remains insufficiently lighted in Ukrainian art criticism. The purpose of the article is to reveal the role of clothing style in forming the image of a contemporary person. The research methodology consisted in the analysis and synthesis, historical and comparative approach, and typological constructions according to art critical criteria of imagery. Based on the complex analysis of notions in the theory and history of design, the concept of style was specified in relation to the basic tendencies of fashion; based on the method of parallel comparison, the realistic picture of development of modern styles of clothing as the basis of image was revealed. The scientific novelty of the work lies in the analysis of scientific data on the issue, its systematization in accordance with modern scientific art critical approaches, and final generalization; addressing the problems of forming/designing the image at the theoretical and practical levels, which, in the conditions of significant interest of various specialists in the fashion industry, does not yet require more detailed scientific art critical comprehension. The disclosure of this issue contributes to the greater effectiveness of designing the image both at the theoretical and practical levels. Conclusions. It was concluded that the image of a person is formed due to various components, where a significant place belongs to the choice of the style of clothing. Knowledge of up-to-date stylistic tendencies of fashion, in particular, couture fashion, and its modifications, is important for solving topical questions of positioning, presentation and self-realization of a person in the society.

Key words: fashion, style, character, image, typology of styles of clothing, stylistic preferences, fashion design, artistic culture, art.

Вступ. Стиль є одним із основоположних понять в мистецькій практиці. Його роль має визначальне значення для архітектури, образотворчого та декоративно-прикладного мистецтва, дизайну, про що свідчать праці істориків мистецтва, починаючи 3 XIX ст. - Г. Вьольфліна, А. Кантора, Е. Ротенберга, О. Каплуна, В. Власова. Однак, якщо на межі XIX-XX ст. Генріх Вьольфлін розглядав історію стилів XVI та XVII ст. 3 точки зору світоглядних особливостей та поняття «краси», то в другій половині XX ст. Свсей Ротенберг 
(1971) аналізував європейські мистецькі стилі XYII ст. як позначені конкретними рисами і виявив на їхньому тлі «внестильову лінію».

Проблеми теорії та історії стилю, його зв'язок із змістом та методами в мистецтві, зокрема в архітектурі, розглянув радянський мистецтвознавець Анатолій Кантор (1962).

Стилям в архітектурі присвятив спеціальне дослідження архітектор Анатолій Каплун (1985), який торкнувся естетичних проблем у системі «стиль образ - ансамбль - синтез».

Найбільш широко поняття «стилю» розглянув В. Власов у трьохтомному виданні словника (1995-1997), який присвячений конкретно цьому питанню. Розглядаючи даний термін, він також заглибився в його етимологічні, історичні, географічні корені, з'ясував підходи до нього різних діячів культури. Узагальнивши широкий історичний фактаж щодо розвитку стилів у архітектурі, графіці, живописі, скульптурі, декоративно-прикладному-мистецтві, автор розкрив нюанси змісту даного поняття. Звернувшись до художніх течій, напрямів, шкіл, творчих об'єднань як практично-діяльної основи, він виявив його складну природу.

Важливим є поняття стилю в дизайні (Михайлова та Федорова, 2016). Однак, попри те, що жодне дослідження не обходиться без звернення до даної проблематики, воно, переважно, розглядається в контексті практичних завдань. Зокрема щодо одягу в такому аспекті воно розглядається в публікаціях I. Гардапхадзе (2004) та Г. Гориної (1982). Цінні рекомендації щодо іміджевого моделювання за допомогою одягу надають також автори, які друкуються під псевдонімом «Сестри Соріни» - психолог Олена Петрова та технолог, керівник школи імідж-клоузінгу Надія Коробцева (2002), питомо із урахуванням психологічних характеристик людини. Психологічні аспекти вибору стилю одягу переважають також у електронних виданнях (Стильный образ с позиции современной психологии, 2015).

Аналізуючи умови виникнення поняття «імідж» ${ }^{1}$ у сучасному суспільстві, такі автори як П. Фролов, Л. Попова, С. Перелигіна, О. Яковлева підкреслюють його «ілюзорну» природу, пояснюючи, що причини його виникнення часто $\epsilon$ результатом бажання приховати реальність від самих себе. Відтак, зміст іміджу $\epsilon$ певною псевдореальністю: його можна створювати, змінювати, підтримувати або руйнувати (Костюченко, 2013, 113-114). Отже, йдеться про зовнішній імідж, який визначається як візуальна привабливість особи (Захаренко, Комарова та Нечаєва, 2003), що формується на основі створення сконструйованого штучного образу засобами дизайну (одягу, зачіски, аксесуарів

\footnotetext{
${ }^{1}$ У нинішньому значенні слово «імідж» (уперше застосував 3. Фрейд) - це не стільки реальний образ людини чи предмета (Ego), скільки ідеальний образ (Super Ego), який, природно відрізняється від реального (Савельева, 1998); цілеспрямовано сформований образ певної особи, явища чи предмета, який підкреслює певні ціннісні характеристики й покликаний створити емоційно-психологічний вплив на когось 3 метою популяризації, реклами тощо; образ, який сприймається і транслюється (створюється і передається), складається з зовнішній вигляду, особистісно-ділових якостей та специфічних моделей поведінки (Шепель, 1997). Відомі різні класифікації особистого іміджу, типології особистого іміджу (Панасюк 1998; Перелигіна 2002, Почепцов 2004 тощо).
} 
і стилю в цілому) у відповідь на будь-які затребувані (актуальні) характеристики і компоненти.

Мета роботи. Визначити базові стилі одягу, їхні характеристики, риси та особливості; обгрунтувати роль одягового стилю у формуванні іміджу сучасної людини.

Виклад основного матеріалу. У різних видах мистецтва, залежно від художньої практики, існують специфічні характеристики стилю, обумовлені їхньою природою та різними способами формотворення, проте наявність об'єктивних засад стилю - історичних, світоглядних, виробничих, дозволяє визначити це явище як єдність образної системи, засобів художньої виразності, творчих прийомів, обумовлених історичними, ідейно-світоглядними, матеріальними, техніко-технологічними факторами. Деякі фахівці визначають стиль як метод, сукупність засобів виразності певної ідеї за допомогою конкретних прийомів роботи, діяльності, поведінки тощо (Лазарєв та Кудінова, 2009). Важливе, провідне місце стилю у дизайні одягу, також обумовлюється тим, що в цій ділянці творчості стиль - це мова, якою користуються автори, створюючи проект, композицію тощо.

Варто відзначити, що у дизайні поняття стилю має окреме визначення щодо просторово-середовищного «контенту» та щодо предметного. У першому випадку, стилем називають художньо-пластичну єдність предметнопросторового середовища i його елементів, що вирізняється у процесі сприйняття матеріальної або художньої культури як єдине ціле (Дизайн: словник-довідник, 2010). В іншому, стиль це - «запатентований» естетичний винахід, що гарантує загальновизнану, об'єктивну естетичну форму, яка набула усталених якостей. Завдяки стилю у дизайні одягу створюється індивідуальність образу, «запрограмованого» на відповідне враження в людському середовищі. На думку деяких фахівців, він дозволяє набути справжньої краси людям, які не наділені суперсмаком, художніми знаннями щодо високого мистецтва тощо (Адмекон / Словарь / Дизайн / Стиль в дизайне,2018).

Сучасний стиль $є$ виключно мобільною, «рухомою» та постійно змінюючою «одиницею», яку штучно створюють дизайнери на основі ретельної аналітики сучасних викликів та вимог споживачів. Відтак свої елементи дизайнерський стиль запозичує в різноманітних джерелах - мистецтвах, науках, будь-яких практиках, утворюючи формальні «конфігурації» образно-візуальних поєднань та «конструкцій». Влучили в саме яблучко, тобто вдалий «симбіоз», визнається відповідним середовищем, приймається, засвоюється у вжитку, невдалий - не сприймається, або ж є специфічним реципієнтом і переходить у несмак, кітч. Натомість для вдалого результату необхідні навички та вміння будування композиції, застосувати сучасні матеріали, техніки й технології для втілення дизайнерських ідей.

Маючи на меті створення іміджу, який є виразником певного стилю, дизайнер використовує власні інструменти - «наробітки» ідей, які сприяють досягненню «індивідуальності» фірмового стилю. Це стосується як «колективного» об’єкта іміджетворення, наприклад, компанії, так і індивідуального (Ауреден, 1996). 
Творення конкретного стилю - процес, який зазвичай відбувається свідомо, цілеспрямовано, «прицільно», коли ставиться завдання, обумовлене певною метою, наприклад, підвищення кар'єрного зросту, прагнення більшої популярності, або визнання громадськістю.

I одним 3 найперших питань щодо створення іміджу людини, постає стиль їі одягу. Він виникає одним із перших, навіть тоді, коли ідея імідж-образу - спонтанна, коли людина не акцентує на цьому процесі уваги, адже їі особа об'єктивно усвідомлюється, конкретизується і фіксується у сприйманні оточуючих саме через одяг (Спенсер, 2000). Отже одяг - це найпотужніша сфера інформування оточення. Його зміна радикально впливає на зовнішній вигляд людини. Навіть попри те, що сама людина може не змінюватися внутрішньо, тобто без «посягань» на психічну організацію, психотип тощо. Вміння «вжитися» в образ іншої людини «на випередження», виступити «режисером» його майбутньої ролі, образу, відповідності запитам суспільства та часу, $\epsilon$ певною вимогою для стиліста - професіонала. На цьому багато в чому базується імідж, що змінює звичні, сталі, укорінені образи людей.

Варто, однак, підкреслити, що розробки конкретного фахівця, зазвичай підпорядковані його власному «фірмовому» стилю, який накладає відбиток на всі його «пропозиції». Як відомо, «впізнаваний» стиль мають всі видатні кутюр'є, як-от І. Сен-Лоран, К. Діор, Д. Гальяно. Власним іміджем володіють і українські дизайнери - Л. Пустовіт, О. Муха, Ф. Возіянов, В. Гресь та ін.

У дизайні одягу стиль, у притаманній йому повторюваності художньооднотипних елементів, має виразну акцентуацію одягового ансамблю, продиктовану конкретними ознаками або їхнью сукупністю. Ознаки формуються за такими критеріями як вік, стать, професія, соціальний статус, приналежність до субкультур, особистий смак, доба, національність, релігійна приналежність, доречність, функціональність, спосіб життя, індивідуальні особливості. Часто стиль визначають акценти, які досягаються кольоровим рішенням, грою на фактурах тканин, особливостями крою. Суттєве місце у стилістиці одягу належить фурнітурі, деталям декору, їх комбінаціям. Важливу роль в ансамблі одягу мають доповнення у вигляді взуття та аксесуарів - головних уборів, шарфів, рукавичок, ременів, ювелірних прикрас (Сигналы личности: о чем говорит ваш наряд?, 2015).

Важливо, що в межах одного стилю може існувати значна кількість його різновидів. Вони $\epsilon$ відображенням сучасних процесів стильової дифузії, наслідком міксування. У результаті виникає нова форма. Її еклектична природа $\epsilon$ інструментом дизайну, одним з базових прийомів стилеутворення і має позитивний характер, адже грунтується на вмінні всебічно аналізувати матеріал i поєднувати його за новими параметрами вжитку. Звідси в одній моделі можуть одночасно бути присутніми елементи кількох стилів, однак в силах дизайнера врівноважити їх між собою, домогтися логічного побудування. Такий творчо-технологічний спосіб роботи саме пояснює у дизайні появу численних стилів, а точніше, стилістичних концепцій.

Натомість, у моделюванні одягу більшість спеціалістів впродовж останніх десятиліть виділяють три основні стилі: діловий, спортивний, 
фантазійний або романтичний (Гардабхадзе, 2004). Питомо, вони функціонально відповідають концепціям класичного одягу (офіційно-діловий стиль), спеціалізованого (спортивний), неофіційного (фантазійний та романтичний).

Сучасній практиці притаманна плутанина рис, стилі можуть взаємно перетинатися, наприклад, діловий може тяжіти до спортивного або до романтичного, спортивний до романтичного тощо. Отже риси стилів можуть проявлятися у безлічі варіантів, зумовлених їх взаємодією та взаємопроникненням, у різних пропорціях насичення в залежності від рішення дизайнера. Той факт, однак, що означені три стилі демонструють усталеність, визначальні риси, їх можна назвати базовими, стилеутворюючими, адже всі решта привносять лише специфічні ознаки, деталі, особливості, які походять від основних.

Психологія та соціологія розглядають дані стилі в певному розподілі - за групами користувачів. Так, діловий стиль, призначений для представників ділової сфери громадського життя, характеризує стриманість, строгість, консерватизм, які обумовлюють вимоги до тканини, кольору, крою, деталей, аксесуарів (Стиль и мода. Стиль деловой женщины, 2012). Діловий стиль належить до одного із затребуваних сучасних стилів.

Основу ділового одягу складає костю́м (від фр. «Costume» - одяг, одіж, сукня) - традиційна верхня одежа з одної тканини, традиційно чоловіча, що включає піджак, жилет, брюки. 3 сер. XX ст. також дамський одяг, що включає жакет, юбку або костюм 3 жилетом і брюками.

Класичний костюм зародився при дворі французького короля Людовіка XIY, а в сучасному вигляді - в XIX ст. у Великобританії. До початку XX ст. його доповнювали тростини і циліндри, білі рукавички тощо. 3 1960-х рр. $\mathrm{XX}$ ст. поширилися костюми-двійки 3 однобортними піджаками як у чоловічому, так і жіночому гардеробі, а в результаті промислової революції та масового виробництва костюм став демократичним та доступним. Нині класичний костюм доповнюють сорочка, краватка або метелик, класичні туфлі, подекуди капелюх, нагрудна хусточка, запонки, кишеньковий годинник з ланцюжком.

Розмаїття костюмів визначається за кольоровою гамою темних та світлих відтінків, виду верхнього одягу (піджак, сюртук, візитка, фрак, смокінг, пальто, плащ), за рядами гудзиків (одно- і двубортні), за наявністю та відсутністю жилета (однобортний, двобортний), за наявністю аксесуарів, за формою лацканів та ін. параметрами.

Всередині стилю виділяють діловий стиль переговорів (костюм, краватка), повсякденний, умовно-діловий («стиль п’ятниці»: джинси, піджак). Суттєве значення у діловому стилі має так званий дрес-код («dress code»«кодекс одягу»), який полягає у дотриманні певної форми одягу, яку вимагають під час відвідання певних заходів, організацій, закладів. Особливо суворий дрес-код у банках, судах, ресторанах. Поняття дрес-коду виникло у Великобританії для означення регламенту, професійно-корпоративної або статусної приналежності людини. Розрізнять дрес-коди White Tie (WT, Formal, Full Dress) - «біла краватка»; Black Tie (BT, Semi-formal, Smoking) - «чорна 
краватка»; Black Tie Invited - «чорна краватка вітається»; Creative «Black Tie»«чорна краватка» 3 творчим підходом; Cocktail Attire - вбрання для коктейлю; Business best (BB) - «найбільш суворий діловий костюм»; After Five (A5) «після п’яти»; After 5 Casual (A5C) - не вимушений вечірній стиль (Дресс-код: стиль одежды деловой женщины, 2012).

Аудиторія ділового стилю є дуже великою. Йому надають перевагу ті, хто претендує на певний статус у суспільстві, хто прагне продемонструвати діловитість і укріпити свій авторитет. До класичного ділового стилю тяжіють люди, яким притаманна внутрішня організованість. Також, цей стиль подобається людям, схильних до усталених норм поведінки, зовнішніх унормувань, перевірених часом.

Не менш популярним сучасним стилем є спортивний. Він виник разом із масовим захопленням спортом наприкінці XIX ст. як особливий, спеціальний за призначенням. Невдовзі спортивний стиль став основою цілого напрямку моди, в якому одежа мала своє походження 3 певних видів спорту. Так, гра в теніс сприяла появі коротких спідниць у складку, шортів, тенісок; кінний спорт появі піджака специфічної форми; ковзанярський і лижний - норвезьких светрів та шапочок. Футбольний одяг - кросівки, футболки, бриджі, стали частиною життєдіяльності сучасної людини.

Зручний, комфортний, демократичний, спортивний стиль налаштований на сферу туризму, спорту, подорожей, прогулянок. Його особливостями є геометричність крою, оздоблювальні фіксуючі строчки, складки, шліци для «запасу об’єму». Тканини, які застосовують для спортивного одягу, мають гарну повітряно- та водопроникність, забезпечують постійну температуру.

Різноманітність, комфортність, практичність, функціональність спортивного одягу обумовлює постійне розширення кола його прихильників, а разом 3 тим і різновидів зразків одягу. Крім традиційних уже повсякденних суконь, костюмів, легінсів, тунік, завдяки так званому гламуру, з'явився спортивний одяг 3 яскравими модними деталями - стразами, вишивками, металевими елементами, квітковим принтом; «спортивний» вечірній одяг - елегантні і дорогі джинси, спідниці, кросівки; класичний - прості лінії та деталі; сафарі iз переважанням кольорів африканської пустелі, ï флори та фауни. Так, комбінування традиційних бомберів зі спідницею сонце-клеш в однаковій кольоровій гаммі, яскраві квіткові візерунки, захисна розмальовка в різних тонах, абстракція, окрас хижих тварин і зіркове небо є модними трендами 2018 року (Лєбєдєва, 2017).

Аудиторія спортивного одягу досить різноманітна. Носіння брюк, вільного одягу з можливістю вільного руху, свободи від офіціозу, зробив спортивний стиль одним із найпривабливіших для молоді. Серед жінок, вважається, що перевагу спортивному стилю віддають ті, хто має активну позицію, цінує демократичні відносини, незалежність, зручність. У чоловіків спортивний одяг заслуговує на величезні переваги перед іншими стилями як зручний і для роботи, і для відпочинку, незалежно, є чоловік прихильником спортивних занять чи ні. 
Романтичний стиль, характеризує тяжіння до суконь, костюмів із спідницею. Романтичний стиль зародився на межі XYIII-XIX ст. як один із проявів загальнокультурного стилю романтизму. У XX ст. його поширення відбулося в 80-ті рр. завдяки принцесі Діані, в гардеробі якої переважали сукні такого типу. Головними рисами романтичного одягу є жіночні силуети, які підкреслюють фігуру, легкі тканини, хвилясті лінії, що утворюють оборки, волани, рюші, драпіровки 3 шифону, органзи, шовку, трикотажу, тонкої шерсті, льону, батісту, атласу, гіпюру. У кольоровій гамі цього стилю переважають білий, світлі та пастельні відтінки, хоча можуть і застосовуватися насичені тони, серед яких найбільш традиційними вважають блакитний, синій, рожевий. Значне місце в романтичному стилі належить квітковим, рослинним, анімалістичним, геометричним зображенням, арабескам, принтам.

Для романтичного одягу притаманні фасони із багатошаровими спідницями, сукні та сарафани із завищеною талією, X- та А-силуети різної довжини, блузки вільного крою або з вузьким ліфом і глибоким декольте, брюки із завищеною талією, жакети й накидки 3 великою кількістю обробки, рукави складної форми й в поєднанні з різними об’ємами, в три чверті, з буфами, «ліхтариками», «дзвонами». Декоративними елементами такого одягу є банти, жабо, мережива, кокильє, вишивка; варіанти застібок з зав'язками, стрічками, нависними петлями, опуклими гудзиками симетрично й асиметрично.

Взуття до одягу романтичного стилю також підкреслено жіночне. Його оздоблюють плетінням, бантами, ремінцями, оборками. Для романтичного стилю притаманні капелюшки, рукавички, шарфи; сумки-клатчі, кисети, ридикюлі, пошети, сумки-конверти; примхливі пояси та ремінці; невеликі ювелірні прикраси, де переважають мотиви квітки, листя, тваринок.

За останнє десятиліття в повсякденному житті цей стиль одягу помітно поступився іншим, більш зручним, і став займати менше місця, ніж на початку XX ст. Одягу в романтичному стилі перевагу надають жінки 3 традиційними патріархальними уставами, зазвичай сентиментальні, які схильні підкреслювати свою жіночність.

Співіснування комфортного стилю (джинси та светри), практичного (плаття-сорочки, твідові спідниці, костюми), романтично-етнічного (довгі сукні, вишивки, мереживо) як у загальному інтертекстуальному просторі моди, так і в окремій колекції є характерною рисою сучасної моди. У моді набуває поширення вільне варіювання різних знакових кодів, що раніше вважалися функціонально несумісними. Втрачає сенс нормативне розмежування денних і вечірніх туалетів. Матеріали, які традиційно вважалися «робочими», «буденними» тепер застосовують в одязі для урочистих раутів. Декольтовані бальні сукні 3 довгими пишними спідницями із джинсової тканини, використання люрексової нитки в ансамблях із традиційного шотландського твіду, шотландка з блискітками - це «оксюморон», поєднання непоєднуваного з погляду класичної моди.

За можливими варіантами вибору одягу відкривається картина розуміння людиною світу і свого місця в ньому, естетичні смаки, ідейні переважання, особливості виховання. Ці моменти впливають на кінцевий результат, а саме - 
імідж людини. Отже, одяг в іміджевому сенсі відіграє принципову роль та значення. Адже, він водночас впливає на механізми соціального сприйняття людини людиною - «стереотипізацію», тобто - приписування шаблонових характеристик людям певної категорії, наприклад, побутових образівхарактеристик, що інтерпретують образно-емоційний тип людини, іiі поведінкові прояви, психотипову схильність. Звідси - інтерпретації образу, які перетворюються на узагальнення, характеристики-типи як-от: «синя панчоха», «фатальна жінка», «душечка», «лялечка», «простачка», «вульгарна особа», «пацанка», «крута дівчинка» тощо (Костюченко та Дихнич, 2016, 344-348). Позначивши категорію, людині автоматично нав'язують набір рис людей даного типу (професійні стереотипи). За стереотипами зовнішнього вигляду люди «фасуються» у відповідний клас. У такий спосіб відбувається розподіл людини до певної соціальної категорії, яка відповідає конкретному стереотипу на умовах змістовного коду, а також утворення сталих уявлень, наприклад, що одяг світлих тонів обирають високоморальні люди, «акуратисти» та естети, мішкувату - скромні й потайливі, суперкоротке міні та яскраву косметику «секс-бомби».

Наукова новизна роботи полягає в аналізі наукових даних із зазначеної проблематики, їх систематизація, відповідно до сучасних наукових мистецтвознавчих підходів, та підсумкове узагальнення; в зверненні до проблематики формування/проектування іміджу на теоретичному та практичному рівні, що в умовах значного інтересу різних фахівців індустрії моди, поки що не потребує більш докладного наукового мистецтвознавчого осмислення. Розкриття даного питання сприяє більшій ефективності проектування іміджу як на теоретичному, так і практичному рівнях.

Висновки. Підсумовуючи, зазначимо, що одяг є виразником іміджевої ролі, яку людина виконує в житті, допомагаючи це створити з максимальним ефектом. На створення іміджу впливають суспільні стереотипи сприйняття, в силу чого презентація іміджу людини як особистості $є$ провідним фактором інформації про неї.

Дизайнерські рішення одягу - символічний засіб кодування смислового повідомлення, де одяг стає матеріальним виразом повідомлень невербальнозафіксованого документального, іконічного та символічного сенсу презентації особистості в ії унікально-індивідуальному самовияві.

Власний (індивідуальний) стиль та імідж формується на основі уявлень про світ, оточення, власне місце у ньому. Психологічна культура у виборі одягу це здатність адекватно висловити у стилі одягу власну унікальність, створити естетичний образ «Я», відобразити в естетичному стилі особистісні переваги; знайти індивідуальну своєрідність в узгодженні естетичних елементів одягу; сформувати власний унікальний імідж; засвідчити розуміння психологічних і естетичних законів кольору і форми. Вдала комбінація кольору, форми і стилю створює індивідуальну, неповторну гармонію створеного зовнішнього образу.

Імідж, пов'язаний із самопрезентацією, $є$ експресивним вираженням власного «Я». Індивідуальний стиль відображає інтереси людини, іiі захоплення, настанови, професійні або фахові зацікавлення як такі, що 
відображають життєвий досвід, спостереження, емоції, преференції щодо певного стилю життя. Це своєрідна репрезентація системи цінностей, світогляду, світосприймання індивідуума.

\section{Список використаних джерел}

1. Адмекон : словарь. Стиль в дизайне [Электронный ресурс]. - Режим доступа: www.advecon.ru/dictionary/designing/style/. - Загл. с экрана. - Дата обращения 29.01.2018.

2. Ауреден Л. Как стать красивой / Л. Ауреден : пер Е. Пилипишека. Москва : Цитадель, 1996. - 226 с.

3. Власов В. Г. Стили в искусстве [Электронный ресурс] / В. Г. Власов. Режим доступа: http://modernstrongwind.weebly.com/blog/-pdf. - Загл. с экрана. Дата обращения 2.03.2018.

4. Гардабхадзе I. А. Основы стиля и имиджа : конспект лекций для студентов-иностранцев / І. А. Гардабхадзе. - Київ : КНУТД, 2004 - 70 с.

5. Горина Г. С. Моделирование формы одежды / Г. С. Горина. - Москва : Легкая и пищевая промышленность, 1982. - 181 с.

6. Дизайн: словник-довідник / За ред. М. І. Яковлєва / Ін-т проблем сучасн. мистецтва НАМ України. - Київ : Фенікс, 2010. - 382 с.

7. Дресс-код: стиль одежды деловой женщины. [Электронный ресурс]. Режим доступу: http://www.ladyboss.com.ua/style/osen-2010-code/. - Загл. с экрана. - Дата обращения 09.10. 2012.

8. Захаренко Е. Н. Новый словарь иностранных слов / Е. Н. Захаренко, Л. Н. Комарова, И. В. Нечаева. - Москва : Азбуковник, 2003. - 783 с.

9. Кантор А. М. О стилях / А. Кантор. - Москва : Совет. худож., 1962. - 79 с. 10. Каплун А. И. Стиль и архітектура / А. И. Каплун. - Москва : Стройиздат, 1985. $-232 \mathrm{c}$.

11. Костюченко О. В. Перцептивні основи образу світу у студентів /

О. В. Костюченко. - Київ : ТОВ. «НПП «Інтерсервіс», 2013. - 444 с.

12. Костюченко О. В. Психологія ефективності фахівця індустрії моди / О. В. Костюченко, Л. П. Дихнич. - Київ : Ліра-К, 2016. - 464 с.

13. Лазарев А. Справочник архитектора / А. Лазарев, Е. Кудинова. - Москва : Феникс, 2009. - 393 с.

14. Лебедева В. Спортивный стиль одежды осень-зима 2017-2018 [Электронный ресурс] / В. Лебедева. - Режим доступа: https://365moda.ru/sportiv nyj-stil-odezhdy-osen-zima-2017-2018-novinki-foto/ - Загл. с экрана. - Дата обращения 09.08.2017.

15. Михайлова Р. Д. Про зміст та співвідношення понять «образ» та «імідж» / Михайлова Р. Д., Федорова С. В. // Вісник КНУКіМ. Серія «Мистецтвознавство». - Київ, 2016. - Вип. 35. - С. 206-217.

16. Панасюк А. Ю. Вам нужен имиджмейкер? Или о том, как создать свой имидж / А. Ю. Панасюк. - Москва : Дело, 1998. - 240 с.

17. Перелыгина Е. Б. Психология имиджа / Е. Б. Перелыгина. - Москва : Аспект Пресс, 2002. - 223 с. 
18. Почепцов Г. Г. Имиджелогия / Г. Г. Почепцов. - Москва : Рефл-бук, Київ : Ваклер, 2004. - 576 с.

19. Ротенберг Е. Й. Западноевропейское искусство XVII века / Е. Й. Ротенберг. - Москва : Искусство, 1971. - 520 с.

20. Савельева О. О. Имидж и имиджмейкеры / О. О. Савельева // Обществоведение в школе. - 1998. - № 6. - С. 18-24.

21. Сорины сестры. Язык одежды, или как понять человека по его одежде: психолог. практикум / Сестры Сорины. - Москва : Гном и Д ; НКФ «Экмос», 2002. $-208 \mathrm{c}$.

22. Сигналы личности: о чем говорит ваш наряд? [Электронный ресурс]. Режим доступа: http://www.diva.by/image/ffl/psihologiya-imidja-natalya-voronova. html. - Загл. с экрана. - Дата обращения 20.01.2015.

23. Спенсер К. Выбери свой стиль для женщин / К. Спенсер. - Москва : ЭКСМО-ПРЕСС, 2000. - $157 \mathrm{c}$.

24. Стиль и мода. Стиль деловой женщины [Электронный ресурс]. - Режим доступа: http://irina-ermakova.com/. - Загл. с экрана. - Дата обращения 20.01.2012.

25. Стильный образ с позиции современной психологии [Электронный ресурс]. Режим доступа: http://styleschool.ru/courses/item/stilnyj-obraz-s-pozicii-sovreme nnoj-psihologii. - Загл. с экрана. - Дата обращения 10.03.2015.

26. Шепель В. М. Имиджелогия: секреты личного обаяния / В. М. Шепель. Москва : Линка-Пресс, 1997. - 168 с.

\section{References}

1. Admekon: dictionary (2018) Style in design. Available at: <www.advecon.ru/ dictionary/designing/style/> [Accessed 21 January 2018].

2. Aureden, L. (1996). How to become beautiful. Translated from English by Pilipishek, Ye. Moscow: Tsitadel'.

3. Dress code: business woman's dress style.. Available at: <http://www. ladyboss.com.ua/style/osen-2010-code/ > [Accessed 9 October 2012].

4. Gorina, G. (1982). Modeling of the form of clothes. Moscow: Legkaya I pishchevaya promyshlennost'.

5. Hardabkhadze, I. (2004). Basics of style and image. Kyiv: Kyiv National University of Technologies and Design.

6. Yakovliev, M. ed. (2010). Design: dictionary-reference book. Institute of Problems of Contemporary Art NAA of Ukraine. Kyiv : Feniks.

7. Kantor, A. (1962). On Styles. Moscow: Sovetskii khudozhnik.

8. Kaplun, A. (1985). Style and architecture. Moscow: Stroiizdat.

9. Kostiuchenko, O. (2013). Perceptual foundations of the image of the world among students. Kyiv: Interservis.

10. Kostiuchenko, O., Dykhnych, L. (2016). Psychology of the effectiveness of a specialist in the fashion industry. Kyiv: Lira-K.

11. Lazarev, A., Kudinova, E. (2009). The reference book of the architect. Moscow: Feniks. 
12. Lebedeva, V. (2017). Sportswear style autumn-winter 2017-2018. O modnoi odezhde. 365moda.ru Available at: <https://365moda.ru/sportivnyj-stil-odezhdyosen-zima-2017-2018-novinki-foto/> [Accessed 9 August 2017].

13. Mykhailova, R., Fedorova, Ye. (2016). On the contents and correlation of concepts «character» and «image». Visnyk Kyivskoho natsionalnoho universytetu kultury i mystetstv [Bulletin of Kyiv National University of Culture and Arts], Series "Art Studies". issue 35. pp. 206-217.

14. Panasiuk, A. (1998). Do you need an image-maker? Or on how to create your own image. Moscow: Delo.

15. Perelygina, E. (2002). The psychology of the image. Moscow: Aspekt Press.

16. Pocheptsov, G. (2004). Imageology. Moscow: Refl-buk, Kyiv: Vakler.

17. Rotenberg, Ye. (1971). Western European Art of the $17^{\text {th }}$ Century. Moscow: Iskusstvo.

18. Savelieva, O. (1998). Image and image-makers. Obshchestvovedenie v shkole [Social studies at school], no.6, pp. 18-24.

19. Sorin Sisters. (2002). The language of clothing, or how to understand a person by their clothes: a psychological practice. Moscow: Gnom i D; NKF «Ekmos».

20. Shepel, V. (1997). Imagelology: Secrets of personal charm. Moscow: LinkaPress.

21. Signals of the person: what does your outfit say? Available at: <http://www.diva.by/image/ffl/psihologiya-imidja-natalya-voronova.html> [Accessed 20 January 2015].

22. Spenser, K. (2000). Choose your style for women. Moscow: EKSMO-PRESS.

23. Style and fashion. Style of a business woman. Available at: <http://irinaermakova.com/> [Accessed 20 January 2012].

24. Stylish image from the standpoint of modern psychology. Available at: <http://styleschool.ru/courses/item/stilnyj-obraz-s-pozicii-sovremennoj-psihologii > [Accessed 10 March 2015].

25. Vlasov, V. (1995-1997). Styles in art. Dictionary. Saint Petersburg: Kolna. Available at: < http://modernstrongwind.weebly.com/blog/-pdf $>$.

26. Zakharenko, E., Komarova, L., Nechaeva, I. (2003). The new dictionary of foreign words: [25,000 words and phrases]. Moscow: Azbukovnik.

(C) Михайлова Р. Д., 2018

(C) Костюченко О. В. 2018 